\title{
Could Isidore's Chronicle Have Delighted Cicero? A Response
}

\author{
Richard W. Burgess and Michael Kulikowski*
}

In Medieval Worlds 3, Jesse W. Torgerson asks whether the work of Isidore of Seville, known in its several recensions as the Chronica, could have delighted Marcus Tullius Cicero. ${ }^{1}$ Torgerson uses the first volume of our Mosaics of Time as a jumping-off point to think about the concept of genre, and about chronicles ancient and medieval. When we wrote this Historical Introduction to the Chronicle Genre from its Origins to the High Middle Ages, we intended it as mere prolegomenon to the editions and commentaries that will follow in later volumes. As the volume grew into a full-length monograph and we dove into scholarly waters far from our native shores, we knew full well we would hit some rocky shoals along the way. We welcomed the controversy that we knew we would prompt in some circles, and we have since been extremely encouraged by the discussions and the challenges we have prompted, particularly amongst Byzantinists. ${ }^{2}$ We approached Torgerson's piece in that same spirit. Trained as classicists and ancient historians, we were expecting a good scholarly rough and tumble, but we appreciate the decorous manner in which Torgerson unfolds what he takes to be critique. For our part, we are impressed by the way Torgerson delivers a remarkable amount of insight, into both genre theory and the work of Isidore, within a small compass. By contrast, we were somewhat disappointed in Torgerson's misapprehensions about our (admittedly very dense) argument in Mosaics I. It seems to us that Torgerson could easily have published his fascinating exposition of Isidore's thought without reference to a word we had written. When the editor of this journal kindly offered us the opportunity to clarify our position, we felt some obligation to do so: we wrote Mosaics I for multiple, sometimes highly compartmentalized, scholarly audiences, and we would not want the audience of medievalists to draw conclusions about our argument from misrepresentation rooted in misunderstanding.

* Correspondence details: Richard W. Burgess, Department of Classics and Religious Studies, University of Ottawa, Desmarais Building, 55 Laurier Ave. East, Ottawa ON Canada K1N 6N5. Email: rburgess@uOttawa.ca. Michael Kulikowski, Department of History, Penn State University, 108E Weaver Building, University Park , PA 16802. Email: mek31@psu.edu.

1 Torgerson, Could Isidore's Chronicle Have Delighted Cicero?

2 E.g., Scott, Review: Weltchronik des Johannes Malalas; and idem, Byzantine Chronicles. See also various papers in Meier et al., Weltchronik des Johannes Malalas. Reviews have been universally constructive and engaged, and generally positive: Adler, Review: Burgess, R. W., and Michael Kulikowski; Brendel, Review: R. W. Burgess u.a.; Brix, Review: R. W. Burgess \& Michael Kulikowski; Bruce, Review: R. W. Burgess, Michael Kulikowski; Fischer, Review: R. W. Burgess/Michael Kulikowski; Flower, Review: Mosaics of Time; Hilkens, Review: R. W. Burgess and M. Kulikowski; Kelly, Review: Mosaics of Time. It is the engagement with our arguments, rather than the approbation, that is essential. 
Torgerson frames his article as a defence of the chronicle (as medievalists understand the word) against our seeming depreciation of it by comparison to the classical genre (or the >Ancient Greek Chronicler as he calls it, though the latter is not a terminus technicus in anything we have ever written). After attempting to summarize our argument, he proceeds to a miracle of scholarly compression, in three excellent pages outlining current genre theory. We wholeheartedly endorse the conclusions Torgerson draws from Daniel Chandler ${ }^{3}$ and John Frow ${ }^{4}$, and especially from the excellent textbook of Anis Bawarshi and Mary Jo Reiff ${ }^{5}$, a book we recommend to anyone in need of orientation in the field. ${ }^{6}$ No one can doubt that, to borrow the language Torgerson quotes from Frow, genre has a social existence and exists in the space created by an author's model for writing and a reader's horizon of expectation (mutatis mutandis the same thing is true of all speech acts). We are unaware of having denied the socially negotiated/constructed nature of genre (or rather its sontology modish formulation), in Mosaics I or elsewhere. But if we inadvertently did so, we hereby and happily retract. In the same way, we would by and large also accept the way Torgerson characterizes Isidore's characterization of what he (Isidore) was trying to achieve in his chronicles, not least because it closely follows the virtuoso interpretation of Henderson's Medieval World of Isidore of Seville ${ }^{7}$. Again, who could dispute that one can extract from Isidore's own words in the Etymologies a political and time-bound as well as a teleological and eschatological meaning, in all his recensions of the Chronica and in his discussion of generic words in the Etymologies. The precise interpretation elaborated by Henderson might be subject to dispute, but as a heuristic for discussing Isidore's possible authorial intentions (also his expectations about the expectations of his audience), it cannot be gainsaid.

But let us turn now to the relevance of Mosaics to all this, such as it is. Below we present a brief summary of what we believe ourselves to have argued in Mosaics, both about the chronicle genre and about why we regard the recensions of Isidore's so-called Chronica as a different, and indeed new, genre. We don't propose to engage with the individual misstatements in Torgerson's text and notes, lest we seem to pick and choose only the most embarrassing. We do, however, invite interested readers (of whom there cannot be many) to read the first eighty pages of Mosaics I and compare them with the respective summaries. There is, however, one misprision that must be corrected explicitly at the start. On his pages 74-75, Torgerson suggests that we reject the possibility of a text's being an >Ancient Greek Chronicler (again, his not our terminus technicus) if it has an indelibly Christian structure. If what Torgerson means by his >Ancient Greek Chronicles is spre-Christian then, on the purely lexical plane, that is a perfectly defensible tautology. But, one wonders, is Torgerson suggesting that we regard (his) >Ancient Greek Chronicler genre as an ideal from which divergence represents decline, and that $a$ fortiori we not only depreciate Christian chronicles but actually deny them status as chronicles?

6 We recommend it especially to those late medievalists we have met who, working with late medieval and early Renaissance vernacular sources, assert that there is no such thing as genre. We would also recommend that in addition to textbooks Torgerson consult Claudio Guillén's seminal Literature as System, which turned György Lukács strictures on the mediation of genre into a functional hermeneutic tool. 
We do not. Had we done so, we should have had little rational motive for taking our discussion down to Sigebert of Gembloux in the twelfth century. Indeed, Mosaics I is replete with examples of indelibly Christian chronicles (not surprisingly, as there had ceased to be non-Christians writing Latin, Greek, or Syriac chronicles after the sixth century at the latest). That is, we nowhere argue for the inferiority or superiority of any one genre, still less any temporal instantiation of any one genre. ${ }^{8}$ Christian chronicles exist, and they are not inferior to non- or pre-Christian chronicles. We have never argued nor will ever argue the contrary. We are, however, arguing that no recension of the Isidorian work generally known as the Chronica is a chronicle by our definition. ${ }^{9}$ To contend that we do so because Isidore's work is indelibly Christian is to manifest a preference for fighting strawmen rather than engaging with scholarship.

Let us be very clear. Indelibly Christian works can be chronicles and were. But the indelibly Christian Isidore of Seville never wrote a chronicle.

Onward, then to our definition of the chronicle genre. We derive it from the characteristics of extant early works, which contemporaries described with the term 'xpovıкá/chronicar. They had in turn derived that title/descriptor from the title of a popular Greek work, now extant only in fragments and attestations, written by Apollodorus in the second century BC. Chief among the extant works from whose characteristics we derive our definitions are the Chronici canones of Eusebius of Caesarea (325) and its translation by Jerome (381), along with the many late Roman continuations of Jerome, from Prosper of Aquitaine to John of Biclar (433 to 605). Having begun there, we then subsumed within this chronicle genre other extant works that shared its characteristics. These works are the Babylonian Chronicle series and many other early Assyrian and Babylonian chronological works; the Parian Marble (263 BC); fragments of Greek Olympiad chronicles on papyrus from the second and third centuries $\mathrm{AD}$ covering the fourth to third centuries $\mathrm{BC}$; the chronicle of Phlegon of Tralles of the mid second century $\mathrm{AD}$; epigraphic Latin consularia of the first century $\mathrm{BC}$ and first century AD; later manuscript consularia in both Latin and Greek from 342 to 630; the Chronographia of Theophanes (ca. 814); literally hundreds of medieval Latin chronicles that medievalists have tended to call rannals' since the days of Georg Pertz; and many of the very late Byzantine Kleinchroniken. Observe that this list includes Christian as well as non- and pre-Christian texts. Indelible Christianity is an irrelevance to the definition of the genre.

The characteristics shared by all these texts are as follows, and no one of these characteristics is on its own sufficient to make a text a chronicle. Our definition (which is argued for at length in Mosaics I pp. 8-58, 278-96), is briefly as follows:

1. The first and fundamental characteristic of a chronicle is its preoccupation with time, хрóvoc. Therefore, every chronicle provides an explicit and often elaborate annalistic chronological structure. The unit into which events are lemmatized is the year. This chronological framework is primary; the content secondary. When practical, therefore, every year can be noted, even if no content exists for some or many years. Conversely, content that cannot be dated cannot be included. That is, chronology can exist without content, but content cannot exist without chronology.

Torgerson seems here to be channeling unconsciously the discourse of Georg Pertz in the earlier nineteenth century and R. L. Poole in the earlier twentieth, best characterized as Medievalist Inferiority Complex: this manifests as a need to defend whatever (putatively medieval) genre one is considering against tacit comparison to the glories of Herodotus, Thucydides, Livy, or Tacitus. We have no dog in this fight.

9 We find that definition reasonable, but others have not, and the ensuing debate has helped us refine our thoughts. 
2. Within these explicitly marked annalistic structures, the events of each year are briefly noted in chronological order. It is this unusual attention to the chronological succession of time that gives the $\chi \rho \circ$ ovıá its name, since no other historical genre prioritizes specific chronologies and the natural succession of time in the way that chronicles do. ${ }^{10}$ However, brevity is not a term that can be defined precisely, and different authors and compilers understood the concept differently: some, like Eusebius, offered only a sentence or two per event or even per year; others, like the compilers of Olympiad chronicles, were more expansive in recounting the detailed events of each year. For that reason, chronicles can fill a single book or many books. But in comparison to classicizing narrative histories, all are very brief recountings of the past.

3. The starting point is sthe beginning`, however that is defined, whether it be the beginning of the world, as in Babylonian or Christian chronicles, or the beginning of history, as from the first Attic king, the first Olympiad, the Trojan War, or Abraham the first Christian.

4. The end point is usually, if not invariably, quite near to the time of the writer.

5. As a function of points 1 to 4 , chronicles are extensive in their chronological coverage - if not in the work of an individual chronicler, then in the chain of works to which an individual chronicler was contributing or continuing. The extensiveness of chronology tends necessarily to give the chronicle genre an air of suniversal coverage. It is, however, a mistake to think that universality is the fundamental characteristic of a chronicle. Other kinds of historical works (like Isidore's, or the Byzantine Cedrenus and Zonaras) are suniversal in the same way, but they are not chronicles. The fundamental characteristic of the chronicle is not suniversality<, but instead its formal treatment of time. That formality is what makes it unique. (As a corollary, and because of this extensive chronological coverage, chronicles are never considered as complete, finished works, but are simply ever-continuing records of history: the tendency to produce continuations of pre-existing chronicles goes back at least to Apollodorus.)

6. Finally, as a result of points 4 and 5 , chronicles are also characterized by parataxis: rand « rather than ১because‘; (Barthesian) consécution rather than conséquence. This parataxis leads to the close textual juxtaposition of what have been called incommensurablesı: events of differing natures and importance sit side by side, a local drought beside the succession of a king. This is the natural result of a brief annalistic record of the past preserved in chronological order.

As should be clear, Cicero's remarks on Atticus' chronicle, which Torgerson appears to think have crucial bearing on our definition, in fact have no such bearing whatsoever. Our reading of Cicero, and indeed of Atticus, plays no role in our definition of the chronicle genre. Atticus' chronicle survives solely in dubious fragments and attestations, but enough does survive to demonstrate that it shared the characteristics with which we define chronicle (see the foregoing points 1 to 6 ). We quote Cicero to make only one point, a point that has nothing to do with defining the chronicle genre but instead addresses the insecurity or status anxiety expressed by scholars writing on chronicles, from R. L. Poole, to Michael McCormick, to recent encyclopedias on the subject. That anxiety derives from a very old, and

10 For a critical appreciation of subjective (Augustinian) vs. natural (Aristotelian) time, and the relevance of each to history, see the literary critic Fredric Jameson's Valences of the Dialectic, 473-612, which wrestles more effectually with Husserl and Heidegger than most philosophers of history have managed. 
frankly spurious, contrast between annalist or chronicler on the one hand, and proper historian on the other. That is to say, we quote Cicero to demonstrate that educated writers of the highest calibre (among whom we also include Cassiodorus) did not reflexively look down their nose at chronicles, and that was the case because they considered the chronicle to be a specific genre with specific generic functions. The chronicle of Atticus could obviously not do what a history like Livy's could do, but the reverse was equally true, and that observation involved (and involves) no value judgement. For Cicero, the virtue of Atticus' chronicle was to have provided a clear, distinctive, and easy-to-use annalistic superstructure within which to contain a highly selective and abridged version of Roman history, a Roman history that was in more expansive form already well known to Cicero. The chronicle allowed one to grasp the temporal relationship of known historical events with an ease and clarity that one had to extract laboriously from narrative history. As we noted above, it is its unique presentation of chronology that distinguishes a chronicle from all other forms of history, and we can see from Cicero's treatises that it was precisely Atticus' presentation of chronology that so delighted him, allowing him to hopscotch through Roman history. We know from other comments that Cicero did not think chronicles were a substitute for history, but he did believe there was nothing better than a chronicle for seeing explicatis ordinibus temporum uno in conspectu omnia. ${ }^{11}$

There is no need to continue. Interested readers can look at Mosaics I p. 63-187 for the stages by which we arrive at our definition, and at p. 20-62 for our taxonomy of genre. ${ }^{12}$ From the foregoing, it should be clear that Isidore never wrote a work that fits our definition of a chronicle, and the fact that he never wrote one has nothing to do with his indelibly Christian content. In all three editions/recensions, Isidore's basic chronological unit was the patriarch/ king/judge/emperor, not the year. He houses these chronological units (rather ineffectually) within a simple count of the number of years since the creation of the world, noted at the end of each leader's life or reign, just as anyone today would list the year BC or AD of each leader's birth or accession. For Isidore, it was the content that was primary, not the chronology. To all intents and purposes, his was simply an annotated list of the succession of leaders from Adam to the Byzantine emperors of his own day. This list and its random historical annotations matter; the chronology is incidental. It is of course true that his historical content is largely derived from Jerome, but that does not make Isidore's work a chronicle. It is closer to the annotated and extended Biblical genealogies that originate at least as early as the Liber generationis of $\mathrm{AD} 235$ and that enjoyed a massive vogue in Byzantium from the ninth century onwards. Because Isidore (and Bede, after him and in part because of him) both took some inspiration, some chronology, and some content from the chronicle, while entirely disregarding its chief structural characteristics, we regard him as founding a new genre. In Mosaics I, we called this genre schronicle epitomer, though we have already been rethinking that choice in the face of reasoned criticism from reviewers and debates with Byzantinist colleagues. Now, Torgerson's feat of misconstrual confirms that we need to find a different term that better conveys generic distinctness, and thus provokes debate rather than error.

11 That Cicero illustrates an ancient author (and reader) discussing how he read and used a work that fits our definition of a chronicle is wholly secondary. The definition precedes the examination of Cicero.

12 See also a defence and refinement of these definitions, particularly with reference to Byzantine universal historiography, accompanied by extensive, analytical excerpts from most surviving such works, in Burgess, Origin and Development. 
Finally, though, could Isidore's schronicler have delighted Cicero? Isidore has many merits, as demonstrated most recently by Henderson, but none of the things for which Cicero praised Atticus can be accomplished with it - one cannot correlate the dates of different events at a glance, or work out how long before or after event $x$ event $y$ took place. That Isidore's Augustinian thought-world was entirely alien to Cicero is neither here nor there, nor is the fact that Roman history as Cicero understood it is effectively absent. What matters is that the continuous annalistic chronology that made Atticus so useful has been stripped out of the Isidorian chronographic frame altogether, at which point nothing Cicero could recognize as historical remains.

Delight Cicero? Isidore would have puzzled him momentarily. Then he would have turned the page and scribbled his shopping list on the verso. 


\section{References}

Adler, William, Review: Burgess, R. W., and Michael Kulikowski. Mosaics of Time, The Latin Chronicle Traditions from the First Century BC to the Sixth Century AD: Volume I: a Historical Introduction to the Chronicle Genre from its Origins to the High Middle Ages, The Medieval Review 14.11.28 [internet]. Retrieved on 28 June 2017: scholarworks.iu.edu/ journals/index.php/tmr/article/view/18742/24855.

Brendel, Ralph, Review: R. W. Burgess u. a.: Mosaics of Time, H-Soz-Kult, 30.09.2013 [internet]. Retrieved on 28 June 2017: www.hsozkult.de/publicationreview/id/rezbuecher-20934.

Bawarshi, Anis and Reiff, Mary Jo, Genre: An Introduction to History, Theory, Research, and

Pedagogy (West Lafayette, 2012).

Brix, Antoine, Review: R. W. Burgess \& Michael Kulikowski, Mosaics of Time. The Latin Chronicle Traditions from the First Century BC to the Sixth Century AD, vol. 1: a Historical Introduction to the Chronicle Genre from its Origins to the High Middle Ages, Scriptorium 67/1 (2013) 16-18.

Bruce, Scott G., Review: R. W. Burgess, Michael Kulikowski, Mosaics of Time: The Latin Chronicle Traditions from the First Century BC to the Sixth Century AD. Volume I: a Historical Introduction to the Chronicle Genre from its Origins to the High Middle Ages, Bryn Mawr Classical Review 2014.05.17 [internet]. Retrieved on 28 June 2017: bmcr.brynmawr.edu/2014/2014-05-17.html.

Burgess, Richard W., The Origin and Development of Early Christian and Byzantine Universal Historiography, in: Sergei Mariev (ed.), Chronicles as Literature, Byzantinisches Archiv 34 (Berlin) forthcoming.

Chandler, Daniel, An Introduction to Genre Theory (1997, revised 2000). Retrieved on June 24, 2017: genreacrossborders.org/biblio/introduction-genre-theory.

Fischer, Andreas, Review: R. W. Burgess/Michael Kulikowski: Mosaics of Time, Sehepunkte 13/10 (2013) [internet]. Retrieved on 28 June 2017: www.sehepunkte.de/2013/10/22698. html.

Frow, John, Genre: An Introduction (London, 2005).

Flower, Richard, Review: Mosaics of Time: The Latin Chronicle Traditions from the First Century BC to the Sixth Century AD, vol. 1: a Historical Introduction to the Chronicle Genre from its Origins to the High Middle Ages, Journal of Theological Studies 65/2 (2014) 772-774.

Guillén, Claudio, Literature as System: Essays toward the Theory of Literary History (Princeton, 1971).

Henderson, John, The Medieval World of Isidore of Seville: Truth from Words (Cambridge, 2007).

Hilkens, Andy, Review: R. W. Burgess and M. Kulikowski, Mosaics of Time: the Latin Chronicle Traditions from the First Century Bc to the Sixth Century AD. Vol. 1: a Historical Introduction to the Chronicle Genre from its Origins to the High Middle Ages, Journal of Roman Studies 104 (2014) 341-342.

Jameson, Fredric, Valences of the Dialectic (London, 2009).

Kelly, Gavin, Review: Mosaics of Time. The Latin Chronicle Traditions from the First Century BC to the Sixth Century AD, I: a Historical Introduction to the Chronicle Genre from its Origins to the High Middle Ages, Journal of Ecclesiastical History 65 (2014), 872-873.

Meier, Mischa, Radtki, Christine, and Schulz, Fabian (eds.), Die Weltchronik des Johannes Malalas. Autor - Werk - Überlieferung, Malalas Studien 1 (Stuttgart, 2016). 
Scott, Roger, Byzantine Chronicles, in: Erik Cooper (ed.), The Medieval Chronicle VI (Amsterdam, 2009) 31-57.

Scott, Roger, Review: Mischa Meier/Christine Radtki/Fabian Schulz (Hgg.): Die Weltchronik des Johannes Malalas, Sehepunkte 16/6 (2016) [internet]. Retrieved on 28 June 2017: www.sehepunkte.de/2016/06/28007.html.

Torgerson, Jesse, Could Isidore's Chronlice Have Delighted Cicero? Using the Concept of Genre to Compare Ancient and Medieval Chronicles, Medieval Worlds 3 (2016) 65-82 [internet]. Retrieved on 28 June 2017: doi:10.1553/medievalworlds_no3_2016s65. 